\title{
OPINION (FOR TRIAL USE) OF THE SUPREME PEOPLE'S COURT ON QUESTIONS CONCERNING THE IMPLEMENTATION OF THE GENERAL PRINCIPLES OF CIVIL LAW OF THE PEOPLE'S REPUBLIC OF CHINA
}

\author{
Translated by Whitmore Gray* and Henry Ruiheng Zheng $†$
}

(Discussed and adopted by the Judicial Committee of the Supreme People's Court on January 26, 1988)

The General Principles of Civil Law of the People's Republic of China ("General Principles") came into force on January 1, 1987. We now issue the following Opinion concerning issues encountered when implementing the General Principles.

\section{Citizens}

A. Questions Concerning Capacity to Have Civil Rights and Competence to Perform Civil Acts

1. The capacity of a citizen to have civil rights begins at the time of birth. The time of birth is that indicated in [the citizen's] ' household registration certificate; where no household registration certificate exists, the time of birth is that indicated in the hospital birth certificate. Where there is no hospital certificate, [the time is determined] by reference to other relevant evidence.

2. A citizen who has completed his sixteenth year but not his eighteenth year who receives income from his own labor and maintains a living standard comparable to that generally enjoyed by local residents may be determined to be a person with full competence to perform civil acts "whose principal source of support is income from his own labor."'?

3. Whether a minor who has completed his tenth year has engaged in a civil activity "appropriate for [one of] his age and intelligence" 3 may be

\footnotetext{
Copyright (C) 1989 by Whitmore Gray and Henry Ruiheng Zheng

* Professor of Law, University of Michigan Law School.

$\dagger$ International Legal Consultant, Sidley \& Austin, Chicago, Illinois; Member of New York and Connecticut Bars.

1. Words in brackets do not appear but are implicit in the Chinese text.

2. Under article 11 of the General Principles of Civil Law of the People's Republic of China [hereinafter General Principles].

3. Under article 12 of the General Principles
} 
determined by considering such things as the extent to which the act relates to his own daily life, whether his mental capacity is sufficient for him to understand and foresee the consequences of his activity, and the amount of money the activity involved.

4. Whether a civil activity of a person suffering from mental illness who is unable to understand fully the propriety of his own acts is "appropriate for [one with] his state of mental health" 4 may be determined by considering such things as the extent to which the activity relates to his own daily life, whether his mental condition is sufficient to understand and foresee the consequences of the activity, and the amount of money the activity involves.

5. A person suffering from mental illness (including mental retardation) who does not have the capacity to make judgments to protect himself and to understand the consequences of his acts, may be determined to be a person who is "unable to understand the nature and propriety of his own acts"; if he does not have the capacity to make judgments as to comparatively complicated matters or relatively important acts to protect himself and to foresee the consequences of his acts, he may be determined to be a person who is "unable to understand fully the nature and propriety of his own acts." 6

6. Where a person with limited competence or an incompetent person accepts an award, donation, or reward, his incompetence or limited competence may not be used as a basis for claiming that his acceptance is invalid.

7. In determining whether a party is mentally ill, the People's Court must [decide] on the basis of a certificate of judicial psychiatric evaluation or by reference to hospital medical diagnosis. Where such an evaluation or diagnosis is not available, whether a party is mentally ill may be determined on the basis of what the general public considers to be his mental health, so long as no interested person objects.

8. If in litigation a party or an interested person claims that the other party is mentally ill (or mentally retarded), and the People's Court considers it necessary to make a determination of the other party's mental capacity, the People's Court must follow the special procedure provided in the Civil Procedure Law (For Trial Use) ("Civil Procedure Law") in first making a judgment as to whether or not the party is competent to perform civil acts.

[If it is a question] whether a mentally ill (or mentally retarded) person is of limited competence, this must be determined with reference to the special procedure provided in the Civil Procedure Law.

9. The place where a citizen has most recently resided continuously for a year or more immediately after leaving his original domicile is considered the "place where he usually resides."7 This, however, does not apply in cases concerning hospitalization for medical treatment.

4. As in article 13, paragraph 2, of the General Principles.

5. Under article 13 of the General Principles.

6. Id.

7. Under article 15 of the General Principles. 
When a citizen has moved from the place of his registered residence, but has not yet moved to a new place, and therefore has no "place where he usually resides," 8 his original registered residence is considered to be his domicile.

\section{B. Questions Concerning Guardianship}

10. The duties of a guardian include: protecting the health of the ward, caring for the ward, managing and protecting the property of the ward, representing the ward in engaging in civil activities, supervising and educating the ward, and representing the ward in litigation when the lawful rights of the ward are infringed upon or where the ward has a dispute with another person.

11. A person's competence to be a guardian must be determined by considering such factors as the state of his health, his economic condition, and the extent of his involvement in the ward's daily life.

12. The expression "close relatives" as used in the General Principles includes a person's spouse, parents, children, brothers and sisters, paternal and maternal grandparents, and children of his sons and daughters. ${ }^{9}$

13. The provisions of article 16 of the General Principles are used in establishing a guardian for a mentally ill minor.

14. When designating a guardian, the People's Court may consider the order of the provisions in clauses 1, 2, and 3 of paragraph 2 of article 16 or clauses 1, 2, 3, 4, and 5 of paragraph 1 of article 17 of the General Principles as a ranking of qualification priority for making its designation. Where a person having priority according to the order to serve as guardian is not competent to be a guardian, or his designation as guardian would obviously be disadvantageous for the ward, the People's Court may, on the basis of the principle of benefitting the ward, make a designation from among those persons having lower priority who are qualified to serve as guardians. If the ward is able to make judgments, his opinion must be solicited as circumstances warrant.

A guardian may be a single person or several persons of the same order of priority.

15. Where a guardian is determined through agreement among those qualified to serve as guardians, the agreement must also specify the responsibilities the guardian or guardians bear in regard to the ward.

16. Where there is a dispute with respect to who should serve as guardian, the relevant organization must first make a designation as provided in paragraph 3 of article 16 or paragraph 2 of article 17 of the General Principles. The People's Court cannot accept any suit brought before such designation is made.

17. Once the relevant organization designates a guardian in accordance with the General Principles and notifies in writing or orally the person

8. Id.

9. For an example of the expression "close relatives," see General Principles, article 17(4). 
designated, the designation must be deemed effective. If a designated person [wishes to] refuse the designation, he must file a suit with the People's Court within thirty days, beginning on the day after the day on which he receives notice of the designation. Where the suit is filed later, it is handled as one involving a change in the guardianship relationship.

18. Once designated, a guardian may not of his own accord change [the designation]. If he makes such a change, after the change the guardian who was originally designated and the guardian he designated bear the guardianship responsibilities jointly.

19. Where a designated person files a lawsuit to reject his designation, the People's Court must issue a judgment affirming or revoking the designation in accordance with paragraph 14 of this Opinion. If the judgment is one revoking the original designation, it may at the same time also designate another guardian. Cases of this kind should be handled in accordance with the special procedure provided in the Civil Procedure Law.

Before the People's Court delivers its judgment, the guardian's responsibilities must in general be borne by persons from among those who are qualified to be guardians in the order of their priority for designation as guardians.

20. Where persons or organizations who are qualified to be guardians under articles 16 or 17 of the General Principles file a lawsuit asking the People's Court to impose civil liability on a guardian for failing to discharge his duty as guardian or for infringing on the lawful rights and interests of the ward, the suit is handled in accordance with the regular civil procedure; a lawsuit demanding a change in guardianship is handled in accordance with the special procedure; where a lawsuit demands both imposition of civil liability on the guardian and a change in guardianship, each demand is handled separately.

21. After divorce, the parent with whom the children live has no right to deny the right of the other parent to exercise guardianship in relation to the children, except when the People's Court deems it possible to deny such a right because the parent who is not living with the children has committed crimes in regard to the children, has mistreated them, or acted as a parent in a manner manifestly harmful to the children.

22. A guardian may entrust his duties as guardian to another person partially or entirely. Unless otherwise agreed, the guardian must bear civil liability for tortious acts committed by the ward, and where the entrusted party is at fault, he is jointly liable.

23. Where after one spouse dies, the other spouse lets the children be adopted, the adoption is deemed valid if it is not harmful to the health and the growth of the children and all the legally prescribed adoption procedures have been followed; other persons qualified to be guardians may not challenge the validity of the adoption by claiming that it was done without their consent. 


\section{Questions Concerning Declaration as Missing and Declaration as Dead}

24. The interested persons who may apply to have a person declared missing ${ }^{10}$ include that person's spouse, parents, children, brothers and sisters, paternal and maternal grandparents, and any other person who has a relationship of civil rights and duties with that person.

25. The order of priority for the interested persons qualified to apply to have a person declared dead ${ }^{11}$ is as follows:

1. spouse;

2. parents and children;

3. brothers and sisters, paternal and maternal grandparents, children of his sons and daughters; and

4. any other person who has a relationship of civil rights and duties [with that person].

Application for revocation of a declaration as dead is not restricted to persons in the above rank order.

26. [The phrase] "a person's whereabouts is unknown" 12 refers to the situation where there is no information about a citizen after he left the place of his last [known] residence. People residing in Taiwan or overseas who cannot be contacted through normal channels of communication may not be declared dead on the basis that their whereabouts is unknown.

27. Where a person's whereabouts becomes unknown during wartime, clause 1 of paragraph 1 of article 23 of the General Principles governs the time period during which an application for declaration of death may be filed.

28. The time period during which a citizen's whereabouts is unknown, as provided in paragraph 1 of article 20 and clause 1 of paragraph 1 of article 23 of the General Principles, starts to run from the next day after information about that citizen is no longer available.

Cases involving the declaration of a person as missing are within the jurisdiction of the Basic Level People's Court for the domicile of the person to be declared missing. Where the person's domicile differs from his residence, the Basic Level People's Court for the place where the missing person last resided has jurisdiction.

29. The declaration of a person as missing is not a necessary procedure precedent to a declaration as dead. Where a citizen's whereabouts is unknown and the circumstances conform to the conditions for a declaration as dead, an interested person may apply directly to declare the person dead without first applying to have him declared missing; where an interested person applies only for a declaration as missing, the person must be declared missing. Where some of the interested persons in the same priority ranking apply for a declaration as dead [even though] others disagree with the [application for a] declaration as dead, the person must be declared dead.

10. Id. art. 20.

11. Id. art. 23.

12. Id. arts. $20 \mathrm{fr}$. 
30. The People's Court designates an administrator to take care of the property of a missing person and must do so in accordance with the principle of favoring the protection of the property of the missing person. Where none of the administrators stipulated in article 21 of the General Principles exists, or none is capable or suitable to be an administrator, the People's Court may appoint other citizens or relevant organizations to be the administrator.

Where a person without competence or with limited competence to perform civil acts is missing, his guardian is the administrator.

31. [The expression] "other expenses" in paragraph 2 of article 21 of the General Principles includes necessary expenses such as those for the support of the missing person's parents, spouse, and children, and the expenses necessary for the administration of his property.

32. Where the administrator of [the property of] a missing person refuses to pay taxes, debts, and other expenses that the missing person owed, and a creditor brings a lawsuit [against the missing person or his property], the People's Court must name the administrator as defendant.

Where an administrator of [the property of] a missing person brings a suit demanding payment of a debt owed to the missing person, he may bring the lawsuit as plaintiff.

33. Where a creditor brings a lawsuit against a debtor whose whereabouts is unknown but has not been declared missing, the People's Court may issue a default judgment after service of process by means of public notice or may suspend the lawsuit.

34. When handling cases involving declarations as missing, the People's Court refers to the special procedure provided in the Civil Procedure Law.

When handling cases involving declarations as missing, the People's Court must make an inventory of the property of the missing person, appoint an interim administrator or adopt other measures to protect the person's property, and publish a public notice regarding the missing person. The period for the public notice is half a year. When the notice period expires, the People's Court declares the person missing or terminates the lawsuit depending on whether the fact that the person is missing is confirmed or not. A judgment declaring the person missing must also designate an administrator for the property of the missing person.

35. Where the administrator of a missing person's property applies to be relieved of his duties on the ground that he is unable to discharge them, the People's Court handles the case in accordance with the special procedure.

Where the administrator of a missing person fails to perform the requisite duties or infringes upon the property rights or interests of the missing person, persons interested in the missing person's affairs may request the People's Court to impose civil liability on the administrator. If the interested persons at the same time apply to the People's Court for replacement of the administrator, that case is handled separately with reference to the special procedure. 
36. The date of death for a person declared dead is the date of the declaration of death. In addition to delivering the judgment document to the applicant, the People's Court must also publish the judgment at the domicile of the person declared dead and at the location of the People's Court.

Where the time of the declared death and the time of the natural death differ, the declared death is legally effective; provided, however, that if civil legal acts [performed by the person] before his natural death contradict the legal consequences of the declared death, his civil legal acts prevail.

37. The marriage relationship of the spouse with the person declared dead is extinguished on the date of the declaration of death. Where a declaration of death is revoked by the People's Court and the spouse of the person declared dead has not remarried, the marriage relationship is automatically re-established from the date when the declaration of death is revoked. Where, however, the spouse of the person declared dead has remarried and then divorced, or was remarried and then became a widow or widower, the marriage relationship is not deemed automatically reestablished.

38. Where during the period when a person was declared dead his or her children are lawfully adopted, upon revocation of the declaration of death the person normally will not be permitted to challenge the adoption by claiming that it was effected without his consent, unless both the adoptee and the adopter agree.

39. Where interested persons conceal facts so that a person is declared dead, and they thereby acquire that person's property, in addition to returning the property and any income derived therefrom they must compensate for any resulting loss.

40. Where a person whose declaration as dead has been revoked requests the return of his property, and the property has already been lawfully acquired by a third party, the third party may refuse to return the property. Citizens or organizations which acquired such property in accordance with inheritance law must, however, return the original property or provide suitable compensation.

D. Questions Concerning Individual Industrial/Commercial Households, Rural Contract-Operation Households, and Partnerships of Individuals

41. In a civil lawsuit, an individual industrial/commercial household having a trade name must name as the party to the lawsuit the head of the household (head of the business) named in the business license, and the litigation documents should identify the trade name and the head of the household which owns the trade name.

42. Where either an individual industrial/commercial household which applied for registration in the name of an individual citizen, or a rural contract-operation household which entered into a contract in the name of an individual, has used property owned in common by the family for investment, 
or where a major part of the household's income is enjoyed by family members, then obligations of the household must be satisfied from family assets.

43. Where during the period of a marriage relationship one spouse engages in an industrial/commercial or contract-operation household, his or her income is co-owned by both spouses, and his or her obligations must also be satisfied from their co-owned assets.

44. Where an individual industrial/commercial household or rural contract-operation household uses property co-owned by the family to satisfy its obligations, the family members must retain items of daily necessity and necessary production tools.

45. In a civil lawsuit, a partnership of individuals having a trade name must name as the party to the lawsuit the lawfully certified and registered trade name and appoint the managing partner as its litigation representative. The acts taken by the managing partner in the litigation are legally binding on all the partners.

In the case of a partnership of individuals without a trade name, the partners are joint parties in a civil lawsuit. Where partners are numerous, the partners may name a litigation representative to participate in the lawsuit. The acts taken by the litigation representative in a lawsuit are legally binding on all partners. The nomination of a litigation representative must be put in writing.

46. Citizens who, in accordance with an agreement, contribute to a partnership in cash or kind and agree to share in the partnership's profits, but do not participate in its management or work, or who provide technical assistance without contributing to the partnership in cash or kind but agree to share partnership's profits, are deemed partners.

47. Externally, all of the partners must be jointly liable for the losses of the partnership in its business activities. Within the partnership, however, the partners must each share the obligations of the partnership as provided in the agreement or in accordance with each partner's share of capital contribution. Where the [partnership] agreement fails to specify these obligations or the capital shares, the obligations of the partnership are shared as agreed among the partners or in accordance with the ratio by which the partners actually share the profits of the partnership. A partner whose fault results in a loss for the partnership, however, must bear a greater share of the liability, depending on the degree of his fault.

48. A partner who only provides technical assistance without contributing to the partnership in cash or kind must also be externally jointly liable for the losses of the partnership incurred in the business operations. Within the partnership, such partner must share the obligations in the ratio provided in the partnership agreement, or in accordance with the ratio of the value of his technical assistance as a share of the capital contributed as provided in the [partnership] agreement; if the agreement provides for neither, such partner bears a share of the obligations of the partnership in 
accordance with his agreed or actual share of the partnership's profit. Where there has been no profit-sharing to establish a ratio, such partner's obligation share is equal to the average capital contribution of the other partners.

49. A partnership of individuals or an individual industrial/commercial household which is registered by mistake by the administrative agencies for industry and commerce as a collectively owned enterprise but which in fact is a partnership of individuals or an individual industrial/commercial household must be treated as a partnership of individuals or an individual industrial/commercial household.

50. Where parties lack a written [partnership] agreement and have not received certification and registration by the administrative agencies for industry and commerce, but have fulfilled all of the other requirements of a partnership, the People's Court may consider the relationship among the parties as a partnership if it is proved by [the evidence of] two or more persons without a direct interest in the partnership that there is an oral partnership agreement.

51. Addition of partners to an existing partnership is governed by the written agreement if the agreement so provides; where there is no provision in the written agreement, the addition of partners must be consented to by all the existing partners; otherwise, the addition of new partners must be deemed invalid.

52. The withdrawal of a partner is governed by the written agreement if the agreement so provides; where there is no provision in the written agreement, withdrawal must be permitted in principle. Where such withdrawal results in loss to the other partners, however, the liability of the withdrawing partner to make compensation for the loss must be determined by considering such factors as the cause and justification for withdrawal, and the degree of fault on both sides.

53. Where a partnership sustains loss in its business operations, a partner who withdrew from the partnership and did not share, or did not reasonably share in the partnership's obligations as agreed to at the time of his withdrawal, is liable for the obligations of the original partnership. A withdrawing partner who has already paid his share of the partnership's obligations remains jointly liable for obligations of the partnership which arose during the time when he was a partner.

54. The property to be divided at the time a partner withdraws must include the partners' contribution to the partnership at the time the partnership was formed, assets acquired during the operation of the partnership, and other rights and liabilities arising during the term of the partnership. In principle, the original property that a withdrawing partner contributed at the time he joined the partnership must be returned to him; where it is difficult to return the original property all at once, it may be returned in installments; where it is difficult to return the original property, it may be [returned] in money. 
55. Upon the termination of a partnership, where there is a written agreement, the partnership's assets are disposed of in accordance with the agreement; where there is no written agreement and the partners fail to agree through consultation, then when the paid-in shares of capital contribution of all of the partners are equal the partnership's assets must be disposed of in accordance with the opinion of a majority of the partners; if the paid-in capital contributions of the partners are not equal, the assets may be disposed of in accordance with the opinion of partners whose capital contributions [together] exceed 50 percent of the total paid-in capital of the partnership, provided, however, that it is necessary to protect the rights and interests of the other partners.

56. Where partners conspire to evade any debt of the partnership, the People's Court must order them to repay the debt; the court may also impose sanctions in accordance with paragraph 3 of article 134 of the General Principles.

57. "Obligations of the partnership are satisfied from the individual property of each partner," as provided in paragraph 1 of article 35 of the General Principles, refers to: satisfaction of the obligations with his own property where the partner used his own property for [his] capital contribution to the partnership; the satisfaction of the obligations with family, co-owned property where the partner used co-owned property for [his] capital contribution to the partnership. Where a partner used his own property for capital contribution to the partnership and used his share of the partnership's profit to support his family members, the obligation of the partnership must be satisfied first from his own property, and any deficiency is satisfied from property co-owned with the family.

\section{II}

\section{Legal Persons}

58. Where the legal representative of an enterprise legal person or [its] other workers cause economic loss to others while engaging in activities in the name of the legal person, the enterprise legal person must bear civil liability.

59. Where an enterprise legal person is dissolved or cancelled, the competent agency must establish a liquidation group to conduct the liquidation of the enterprise. When an enterprise legal person is declared bankrupt, the People's Court must organize the concerned agencies and any concerned persons to establish a liquidation organization to liquidate the enterprise.

60. A liquidation organization is an organization established in accordance with law for the purposes of liquidating the assets and liabilities of an enterprise legal person. It has the responsibility to care for, put in order, value, dispose of, and distribute the property of a terminated enterprise legal person, and to satisfy its debts.

A liquidation organization may use its own name in participating in lawsuits involving the assets and liabilities of the enterprise legal person. 
The civil acts of a liquidation organization established for the purpose of evading debts are void.

61. If when handling a case the People's Court determines that an enterprise legal person has committed any one of the six acts listed in article 49 of the General Principles, the court, in addition to imposing liability on the enterprise legal person, may impose a fine directly on the legal representatives of the enterprise in accordance with article 49 and paragraph 3 of article 135 of the General Principles. Where there is a need for administrative sanctions, judicial recommendations may be proposed to the government department concerned, which decides and handles the matter; where a crime is involved and there is a need to impose criminal liability, the case must be transferred to the public security bureau or the procurator's office in accordance with law.

62. Where during its handling of a case the People's Court decides to impose sanctions such as fines or detention on the legal representative of an enterprise or on other persons, such decision must be approved by the President of the People's Court, and must be specified in a separate written civil penalty order. If the person subject to the penalty disagrees with the decision, he may apply to the People's Court at the next higher level for review within ten days after receipt of the order. Execution of the order is suspended during review.

63. Fines imposed against legal representatives are ordinarily [limited to] 2000 yuan or less, unless the law provides otherwise.

64. A party to a joint operation who contributes land-use rights should share the obligations of the joint operation as provided in the written agreement; where the written agreement does not so provide, the obligations of the joint operation are shared according to the paid-in capital or profitsharing ratio.

\section{III}

\section{Civil Legal Acts and Agency}

65. Civil acts performed by a party in the form of audio recording, video recording, or other audio or material means is deemed valid if two or more disinterested persons act as witnesses or if there is other proof that the civil acts conform to the provisions of article 55 of the General Principles.

66. Where one party claims a civil right against another party, the claim is deemed accepted by acquiescence if the other party fails to express his intention orally or in writing but his [failure to] act indicates acceptance. Otherwise, acquiescence by failure to act is considered an expression of intention only when the law so provides or the parties mutually agree.

67. The civil acts of a person who suffers intermittent mental illness must be deemed void if it is proved that the acts were performed while the person was mentally ill. 
Civil acts performed by a person in a state of unconsciousness must be deemed void.

68. An act is deemed an act of deceit if one party willfully misrepresents to or deliberately conceals from another party facts and thereby induces the other party to make a mistaken expression of intention.

69. It is deemed an act of duress if a citizen forces another citizen to make an expression of intention contrary to his true will by threatening harm to such things as the life, health, honor, reputation, or property of a citizen or his relatives, or threatening harm to such things as the honor, reputation, or property of a legal person.

70. It is deemed an act of taking advantage of another party's distress if a party, in order to secure an unjust benefit, takes advantage of another party's distress to force the other party to make an expression of intention that is contrary to his true will, thereby severely damaging his interests.

71. A serious error is deemed to exist where a person performing an act misapprehends the nature of the act, the [identity of the] other party concerned, or the kind, quality, specification, and quantity of the subject matter, so that the consequences of his act are contrary to his true intention, thereby resulting in significant loss.

72. An act is deemed grossly unfair where one party exploits his advantageous position or another party's inexperience in such a way as to violate flagrantly the principles of fairness and of exchange of equivalent values. ${ }^{13}$

73. Where a party requests modification of a civil act which was a result of a significant error or is grossly unfair, the People's Court must grant the modification; where the party requests rescission, the People's Court may grant either modification or recission, depending on the circumstances.

The People's Court will not provide protection with respect to any civil act eligible for modification or rescission if the party fails to request the modification or rescision within one year after the act was performed.

74. "Property acquired by them" as provided in paragraph 2 of article 61 of the General Principles must include property that both parties have already obtained as well as property that both parties have agreed to obtain.

75. A civil act subject to a condition must be deemed void if the condition attached violates the law or if it is impossible for the condition to occur.

76. Civil legal acts subject to a time limit become effective or discharged in accordance with the beginning or expiration of the time limit.

77. Where [a person's] expression of intention is to be communicated by a third party, and the third party, due to negligence, miscommunicated or failed to communicate [ the expression of intention], thereby causing a loss to another person, the person making the expression of intention ordinarily may

13. Id. art. 4 . 
be held liable for the loss, unless otherwise provided by law or otherwise agreed by both parties.

78. Where either the law or an agreement among the concerned parties requires that a civil act be performed by a person himself, the act must be deemed void if the person does not perform the act himself.

79. Where several appointed agents ${ }^{14}$ act jointly, and an act performed by one or more of them without consulting with the other appointed agents infringes upon rights and interests of the principal, the appointed agent or agents who performed the act bear civil liability.

Where there are several principals and one or more of them, without the agreement of other principals, undertake ${ }^{15}$ to terminate the agency relationship, thereby resulting in loss [to the principals], the principal or principals who undertook to terminate the agency relationship bear liability.

80. "Emergency situation," as provided in article 68 of the General Principles, refers to the situation where, due to special reasons, such as sudden, serious illness or loss of communication contact, the appointed agent cannot himself take care of the matters he has been entrusted with under the agency and cannot contact the principal, and thus the interest of the principal will be damaged or the damage will be aggravated unless the agent transfers his authority to a third person.

81. An appointed agent who transfers his authority to a third person should complete the formalities stipulated in article 65 of the General Principles. A third person who suffers loss because the appointed agent does not make a clear transfer of his authority may claim damages directly from the principal as compensation for his loss, and the principal, after satisfying the civil liability, may claim indemnification from the agent who made the transfer; if the agent to whom the authority was transferred is at fault, he is jointly liable.

82. After the principal dies, an act performed on his behalf by an appointed agent is effective where any one of the following circumstances exists: (1) the appointed agent is not aware of the death of the principal; (2) the successors of the principal agree to ratify the act; (3) the principal and the agent had agreed that the agency would terminate only after the matters entrusted to the agent under the agency had been completely taken care of; [or] (4) the act was already under way before the principal died, and continued performance until completion is in the interest of the successors of the principal.

83. Where the agent and the principal are jointly liable for a civil act which has been performed they may be named as joint parties to a lawsuit.

14. See id. art. 64. The sense is an agent appointed by a principal and could be translated "agent by agreement."

15. The Chinese (iichu) literally means "suggests" or "proposes," but the sense seems stronger than that. 


\section{Civil Rights}

\section{E. Questions Concerning Ownership and Property Rights Related to Ownership}

84. Where property has been delivered but the parties agreed to attach a condition to the transfer of the ownership of the property, the ownership of the property is transferred when the attached condition occurs.

85. Where one party demands rescission of a transaction after ownership of the property has been lawfully transferred, [such a demand] is not to be supported. Where, before ownership of property has been transferred in accordance with an agreement, one party requests rescission of the transaction without legitimate cause and the agreement can still be performed, performance must continue; where the agreement cannot be performed, and loss is thereby caused to the other party, the party [who failed to perform the agreement] must pay for the loss.

86. Where a non-owner uses the property of another person and makes an addition to the property, if the owner agrees to the addition and the parties agree on the disposal of the addition when the property is returned to the owner, then the addition is disposed of as agreed; where there is no prior agreement and the parties cannot agree on the disposal of the addition through consultation, the addition may be ordered dismantled if dismantling is possible; where dismantling is impossible, the addition may be given to the owner of the property upon his payment of the value of the addition. If the addition or the dismantling thereof results in a loss to the owner of the property, [the person who made the addition] must pay for the loss.

87. Ownership of things attached to property is transferred with the transfer of the ownership of the property; however, where the concerned parties have agreed otherwise as to the disposal of the things attached, and the agreement does not violate the law, the things are disposed of as agreed.

88. Where in the case of co-owned property some of the co-owners claim that the property is co-owned by shares and others claim that the property is co-owned jointly, the property must be deemed to be co-owned jointly unless co-ownership by shares can be proved.

89. Joint co-owners each enjoy the same rights and have the same obligations towards the property under joint co-ownership. During the period of joint co-ownership, the disposal of the property by some of the coowners without the consent of the other co-owners is generally deemed void. Where a third party obtains the property in good faith and for value, however, the lawful rights and interest of the third party must be protected, and any loss to other co-owners must be compensated for by the co-owner or coowners who disposed of the property on their own [without the consent of the other co-owners].

90. Upon the termination of a joint co-ownership, the property under the joint co-ownership is divided in accordance with the agreement of the co- 
owners if such agreement exists; in the absence of agreement, the property is divided in accordance with the principle of equal division, taking into account such factors as the contribution of the co-owners to the property and the actual production and living requirements of each co-owner. The division of property co-owned by spouses, however, must be handled in accordance with the relevant provisions of the Marriage Law.

91. Where property under co-ownership is a specific object which is not divisible, or which will lose value if divided, [division] may be effected by converting [the property] into cash. ${ }^{16}$

92. Where one or more joint co-owners [wish to] sell their shares in property after property under joint co-ownership has been divided, if the portion of the property to be sold and the portion of the property obtained by other joint co-owners belong to one complete unit or are used as a set, a claim by other joint co-owners of a priority right to purchase [the property to be sold] must be upheld.

93. Where a citizen or a legal person excavates or discovers buried or concealed property, his or its right to the property must be protected if there is proof that the property belongs to him or it, and if under the current law and policy the property may be so owned.

94. The finder of lost property bears no civil liability for unintentional destruction or damage to the property. Where the finder of lost property keeps the lost property as his own and refuses to return it [to the owner], a lawsuit resulting therefrom is handled as an action in tort.

95. The rights and obligations of citizens and collectives arising from lawful contracts for the use and operation of forests and woods, land, mountain land, grassland, undeveloped land, shoreline, and bodies of water that belong to collectives or that belong to the state but are used by collectives, are determined in accordance with the provisions of those contracts. Without the consent of the grantor of [those rights under] the contract, any subcontracting or transfer [of rights] by the grantee is void.

96. Any dispute with respect to the right to use or to own land, mountain land, forests and woods, grassland, undeveloped land, shoreline, bodies of water, and other such natural resources must first be handled by the relevant administrative agencies. A party who disagrees with a decision of an administrative agency may bring a lawsuit in the People's Court in accordance with the relevant provisions of law and administrative regulations. The People's Court, however, may directly accept and handle cases based on tort [arising from such relationships].

97. Where, as a result of construction, a party temporarily occupies adjacent land belonging to another party and fails to use the land in accordance with the parties' agreement concerning the scope, purpose, and duration of the use, the [occupying] party must be ordered to clean up the

16. The sense herc is to sell it and divide the cash. 
site, eliminate the obstructions, restore the property to its original state, and make compensation for losses.

98. Where one party on his own authority cuts off or monopolizes the natural water flow, thereby [adversely] affecting the normal production and living activities of another party, the [adversely] affected party has a right to request the elimination of the obstructions; if the party obstructing the natural flow has caused loss to the other party, he must be held liable to compensate [for the loss].

99. Where one party has to use the adjacent land of the other party for drainage purposes, the other party must permit such use; the party must, however, limit the use of the other party's land to what is necessary and adopt appropriate measures [to protect the other party's land]; if such use nonetheless results in loss to the other party, the party who received benefit from the use must provide reasonable compensation.

Where, because of a failure to adopt reasonable methods of drainage he might have adopted, a party allows water to flow into adjacent land, thereby causing loss or making it likely that loss will be caused to the property of another party, if the other party demands that the party causing the loss cease the infringement, remove the danger, restore the property to its original state, and compensate the loss, his demand must be upheld.

100. Where it is necessary for one party to pass through adjacent land of another party, such use must be permitted; if such a use causes loss [to the other party], appropriate compensation must be provided.

101. Where there is a route of passage through a building area that has over time become necessary, the person who owns or has the right to use the building must not block the route. Where blocking the route adversely affects the production or living activities of another person and the other person demands the elimination of the obstruction or restoration of the property to its original state, such a demand must be upheld; however, where it is feasible, another route of passage may be established.

102. In disputes over the dripping of water from the roof of one house onto the roof of an adjacent house, a party who is at fault and causes loss to the other party must be ordered to eliminate any obstruction and compensate for any loss.

103. Where a party digs things such as ditches, ponds, or cellars, or on the land he uses grows plants that have overreaching roots or branches, thereby endangering the safety and the normal use of his neighbor's adjacent building, the party must be ordered, depending on the circumstances, to remove the danger, to restore the property to its original state, [and/or] to compensate for the loss.

\section{F. Questions Concerning Obligations}

104. Where an obligee rejects without good cause the performance of an obligor and the obligor deposits the object of the performance in the care of an appropriate agency, the obligation must be deemed performed. Any 
expenses incurred by the agency in caring for the object should be borne by the obligee. While the object is in the care of the agency, any interest accruing from the property belongs to, and the risk of loss is borne by, the obligee.

105. According to the provisions of clause 1 of paragraph 2 of article 88 of the General Principles, if a contract does not clearly specify the quality standard of a product, the parties to the contract fail to reach agreement thereon, and the state has issued no pertinent quality standard, then the standard promulgated by the appropriate ministry or that generally acceptable within the industry controls. Absent a ministry or industry standard, the approved enterprise standard should be followed. If an approved enterprise standard does not exist, the approved standard of similar products of other enterprises in the same industry in the place where the subject matter of the contract is produced controls.

106. A guarantor must be a citizen who, or an enterprise legal person or other economic organization that, possesses the financial capacity to pay on behalf of the obligor. Even if a guarantor does not possess the financial capacity to pay the entire obligation of the obligor, he still must use his own property to perform the guaranty obligation.

State organs may not serve as guarantors.

107. If a branch of an enterprise legal person that is not qualified as a legal person enters into a guaranty contract under its own [branch] name, the contract must ordinarily be deemed void. However, where the branch incurs any financial liability arising therefrom, the branch must itself bear the liability if it is able to pay. If the branch is unable to pay, the enterprise legal person must bear the liability.

108. Where a guarantor guarantees to an obligee the performance of an obligor, the guarantor and the obligee must enter into a written guaranty contract providing for the extent and duration of the guarantor's obligation concerning the performance by the obligor of the main obligation. Where there is no separate written guaranty contract but the main contract nevertheless specifies the extent and duration of the guarantee, and the guarantor has attached his signature and seal, a written guaranty contract is deemed established. Unless the law provides otherwise, a guaranty made orally between citizens is also deemed a guaranty contract if such guarantee is verified by two or more disinterested persons.

Where the extent of the guarantee is not clear, the guarantor is deemed to guarantee the entire obligation of the obligor.

109. During the term of a guaranty, the extent of the guarantor's obligation decreases as the main obligation of the obligor decreases. However, the guarantor does not have an obligation to guarantee any newly increased obligation unless the guarantor has otherwise agreed.

110. Two or more guarantors are jointly liable for the performance of the guaranteed obligation, unless the guarantors and the obligee agree that 
each guarantor guarantees a specific share of the performance of the obligation.

111. Where a guaranteed economic contract is deemed void, unless otherwise specifically agreed by the parties, the guarantor remains jointly liable if the party [whose obligation is] guaranteed must return the property or compensate for any loss.

112. Where an obligor or a third party pledges property to the obligee, a written contract must be concluded or the original document of indebtedness must specify the pledge. Absent a written contract, the pledge may be deemed established if there is other evidence to show that the pledged property or other documents of title have been delivered to the pledgee.

113. A pledge must be deemed void if the pledgor does not own or does not have a right to operate and manage the pledged property.

If pledged property whose marketability is restricted by law is to be used to satisfy the obligation, it must be purchased by an appropriate agency, and the pledgee enjoys a priority right to obtain compensation from the proceeds of the sale.

114. If pledged property is destroyed or damaged while in the custody of the pledgee, and the pledgee is at fault, he must bear civil liability.

Where pledged property is destroyed or damaged while in the custody of the pledgor, the pledge relationship must be deemed [to continue] to exist, and the pledgor must be ordered to replace the property.

115. Where pledged property is in the possession and care of the pledgor, and the pledgor, without the consent of the obligee and while the pledge is in effect, transfers the property to another person, or pledges a part of the property that is subject to the pledge to other obligees, such transfer or pledge is void.

Where an obligor uses the pledged property to satisfy the obligation, and more than one pledgee has a claim to the same pledged property, the pledgees must be paid in the order in which each pledge was created.

116. Where there are several obligees, some of whom demand the repayment of bank loans and some of whom demand performance of other obligations, the obligees who have pledge rights must be accorded a priority right to be paid, except where the law or regulations provide otherwise.

117. Where, on the basis of a contract relationship, an obligee takes possession of property belonging to an obligor, the obligee may retain an appropriate amount of the property if the obligor fails to perform his contractual obligation when due. If the obligor, after receiving several notifications [urging compliance with the contract], still continues to refuse to perform the obligation within a reasonable time, the obligee's [right to] sell the retained property at a reasonable price and obtain compensation by priority right out of the proceeds [of the sale] must be protected.

118. Where a landlord intends to sell a house that is under lease, he must notify the tenant three months prior to the sale. The tenant has a priority right to purchase the house on the same terms. Where the landlord fails to 
follow these provisions when selling his house, the tenant may apply to the People's Court to have the sale of the house declared void.

119. Where a house is rented by a family but in the name of only one person, if the person under whose name the house was rented dies while the lease is in effect, a request by the co-residents of the same family for the continuation of the lease must be approved.

Where ownership of a house under lease is transferred as the result of sale, donation, or inheritance, the original lease remains in effect between the original tenant and the new owner.

Where a lease does not specify a term, a demand by the landlord to take possession of the house for his own use ordinarily must be permitted. A tenant who is able to move must be ordered to vacate the premises; if the tenant has difficulty in moving out, however, the tenant may be given a limited grace period to look for another house or may be ordered to vacate part of the house.

120. During the term of a mortgage ${ }^{17}$ on a house, or upon its expiration, the parties must be permitted to extend the terms of the mortgage or to increase or decrease the redemption price of the property through agreement. The demand of a mortgagee that the mortgagor pay more than the originally agreed price of the property ordinarily is not to be upheld. If the mortgage interest in the property is treated as lawfully marketable, the price must be the market price at the time of redemption. ${ }^{18}$

121. In loans between citizens, where parties have agreed on the time of repayment or return, the loan relationship must be handled in accordance with that agreement. Absent such an agreement, a lender may demand repayment or return at any time, and the borrower must promptly effect repayment or return as demanded; however, if the borrower is temporarily unable to repay or return, he may, depending on the actual circumstances, be ordered to repay the debt in installments.

122. The interest rate for loans among citizens for production or business operations may be appropriately higher than that for consumer loans. Disputes concerning interest rates must be resolved in accordance with the principles of protecting lawful credit relationships, of taking the actual circumstances into account, and of promoting production and stability of the economic order.

123. In the case of interest-free loans between citizens, the lender must be permitted to demand payment of interest on any unpaid principal if the borrower fails to repay the loan by the agreed repayment date, or in a case

17. Dian is a traditional Chinese form of security interest. The translation "mortgage" is used since that is our normal term for the interest in a house used as security. See definition in $P$. Bilancia, Dictionary of Chinese Law and Government 632 (1981).

18. Or "Where the parties agree to set the redemption price in accordance with lawful market rates, the price must be the market retail price of the mortgaged property at the time of redemptions;" or "If the mortgaged property is lawfully marketable, the redemption price must be 
where there is no prior agreement as to the time of repayment, after the lender demands repayment.

124. Where disputes arise between parties as to interest rates on money loans, if the agreement is unclear and neither party can provide proof, the interest must be calculated according to the interest rate on similar loans made by banks at the time the loan was made.

125. As to loans between citizens, a lender who adds interest to the principal and thereby charges compound interest is not to be given protection. Where a lender deducts the interest at the time a loan is made, the interest must be calculated on the basis of the amount actually loaned.

126. As to loans in kind, a lender's demand for the return of the original property or of property of equivalent quantity and quality must be sustained; if it is impossible to return the original property, the lender may be compensated in cash in an amount equal to or appropriately higher than the retail price [of the goods].

127. If a borrower of goods destroys or damages the borrowed goods through inappropriate management or use, the borrower must bear liability for the loss; [but] if the borrowed property is defective, the liability of the borrower may be reduced.

128. Gifts between citizens are deemed effective when the gift is delivered. Where a house is given, the gift must be deemed effective if title is transferred through completion of the registration procedure specified in the written contract of gift. Absent registration of the transfer of title, a gift [of a house] may nevertheless be deemed effective if the donor has delivered a document of title to the donee in accordance with a written contract of gift and the donee has already entered into possession and use of the house in accordance with the contract of gift; the parties must, however, be ordered to register the transfer of the title.

129. Where a donor clearly indicates that he intends to make a gift to a minor, the property given must be deemed the minor's own property.

130. If a donor gives property to another person for the purpose of evading his legal obligations, the gift must be deemed void if interested parties claim their rights.

131. In returning improper[ly received] benefit, one must return the original property plus any accrued interest. Any other benefit gained through making use of the improper benefit must be confiscated after a deduction for [the value of] labor and for management expenses.

132. The "necessary expenses" that a person who provides care or service may demand from the person who received the benefit, as provided in article 93 of the General Principles, include expenses directly resulting from the care or service and actual losses sustained as a result of the care and service.

\section{Questions Concerning Intellectual Property Rights and Personal Rights}

133. An author enjoys the right of authorship (copyright) whether or not a work has been published. 
134. If two or more persons jointly write a work in accordance with an agreement, the work must be considered jointly written without regard to the relative contribution of each person to the work.

135. The right of authorship (copyright) of a work co-authored by two or more persons must be deemed to belong jointly to all the co-authors; [but] if each part of the work exists independently, the right of authorship (copyright) to each part belongs to the author who wrote that part.

136. If, after an author dies, there is an infringement of a property right that is derived from authorship (copyright) that has been inherited by an heir, and the infringement occurs during the period stipulated by law for protection of such a right, the People's Court must uphold any lawful demand for protection raised by the heir.

137. A patent right that a citizen or a legal person receives through patent application or through inheritance, gift, assignment, or the like must be protected.

The transfer of a patent must be registered and announced by the State Patent Office, and the patent is deemed transferred on the date when the transfer is announced.

138. A trademark right that a legal person, an individual industrial/commercial household, or a partnership of individuals has received through application for trademark registration or through other methods, such as assignment, must be protected unless such a right has been revoked in accordance with legally prescribed procedures.

A transfer of a trademark right must be approved by the Trademark Office of the State Administration for Industry and Commerce, and the trademark right is deemed to be transferred on the date of the approval.

139. Using a citizen's likeness as an advertisement, trademark, or store window decoration without his consent and for profit must be deemed an infringement of the citizen's right to his likeness.

140. Any act, written or oral, that exposes another person's private secrets to the public, that fabricates facts in order to defame publicly a person's dignity, or that employs insult or defamation which clearly damages another person's reputation, must be deemed an infringement of a citizen's right to his reputation.

Any act, written or oral, that damages or defames the reputation of a legal person and that causes loss to the legal person must be deemed an infringement of the right of a legal person to its reputation.

141. Appropriating or fraudulently using another person's surname [and/or] given name, thereby causing loss, must be deemed an infringement of a person's right to his surname and given name. 


\section{Civil Liability}

142. Where a person sustains a loss in the course of protecting the lawful rights and interests of the state, collective, or an individual, and if the tortfeasor [whose actions threatened those rights and interests] is unable to pay, or if there is no tortfeasor, then, upon the request of the injured party, the People's Court may, based on the amount of benefit that the beneficiary received and his or its financial condition, order the beneficiary to provide appropriate compensation.

143. The length of loss of work by an injured party must be determined on the basis of the actual injury and the state of his recovery, making reference to the documentation provided by the hospital which treated the injured party or forensic expert evaluation. The amount of damages may be determined on the basis of the salary or the actual income of the injured party.

Where the injured party is a contract-operation household or an individual industrial/commercial household, the standard for determining the loss of income from work may be determined with reference to the average income of the injured party over a certain period of time. If the injured party has contracted to undertake cultivation or husbandry operations that are so seasonal that a greater loss will result unless the business is promptly taken care of, then apart from the obligation of the injured party to take action to prevent aggravation of the loss, the tortfeasor may also be ordered to take such action.

144. Compensation for medical expenses must ordinarily be based on the diagnosis certificate of the local hospital which treated the injured party and his receipts for medication and hospitalization. Medical expenses incurred as a result of the injured party's seeking treatment in another hospital without the approval of the appropriate medical institution when such an approval is required ordinarily is not granted. Expenses incurred by the injured party as a result of the unapproved purchase of medication unrelated to the injury or for treatment of other illnesses is not compensated.

145. Compensation for loss of income from work to a person specially approved by a hospital to nurse an injured person is based on the actual loss of the income. Such compensation may ordinarily include a bonus which the person would otherwise have received. If the person is not salaried, the standard of compensation should be limited to the average wages received by local temporary workers.

146. Where a person receives bodily injuries which cause a total or partial loss of his ability to work, compensation for his living expenses ordinarily must not be lower than the basic living standard of local residents.

147. Where a person receives bodily injuries which cause his death or the loss of ability to work, and where those dependent on him for support lack other sources of livelihood and demand that the tortfeasor pay their necessary 
living expenses, such a demand must be approved; the amount of compensation for living expenses is determined in accordance with the actual circumstances.

148. A person who instigates or helps another person to commit a tort is a joint tortfeasor and must bear joint civil liability.

A person who instigates or helps another person who is incompetent to commit a tort is a tortfeasor and must bear civil liability.

A person who instigates or helps another person with limited competence to commit a tort is a joint tortfeasor and bears the primary civil liability.

149. Defrauding or deceiving another person by mail, telecommunications, or other means, or through misappropriating or counterfeiting another person's name, thereby causing damage to that person's property or reputation, is a tort, and the tortfeasor must bear civil liability.

150. Where a citizen's right to his name, likeness, reputation, or honor, or a legal person's right to its name, reputation, or honor, is infringed, and the citizen or the legal person makes a demand for compensation for the loss, the People's Court may determine the liability for compensation based on the degree of fault of the tortfeasor, the specific circumstances of the infringement, and the consequences and impact of the infringement.

151. Where a person infringes another person's right to his name, likeness, reputation, or honor and thereby receives profit, not only does the tortfeasor compensate the loss of the injured party, but also the tortfeasor's unlawful income gains must be confiscated.

152. Where a worker in a state agency in the course of performing his official duties interferes with and causes damage to the lawful rights and interests of a citizen or a legal person, thereby causing loss, the state agency must bear civil liability.

153. Where the use of goods of sub-standard quality causes personal injury or property loss to a consumer, user, or another person, the injured party suffering the loss may demand compensation from the manufacturer or seller. Any lawsuit arising therefrom is within the jurisdiction of the People's Court at the place where the defendant is located or where the infringement took place.

Where a transporter or a bailor is responsible for the [bad] quality of the goods, and a manufacturer or retailer demands compensation for losses, the case may be handled separately or together [with the original lawsuit], naming the transporter or bailor as a third party to the litigation.

154. Where, without adopting necessary safety measures as required by the relevant regulations, a person engages in work which constitutes high risk to the surroundings, thereby seriously endangering the safety of the person or property of another, the People's Court must, at the request of the person endangered, order the person to eliminate the danger.

155. Where a person is injured as a result of the falling of goods piled up by another party, if neither party is at fault, the dispute must be handled in 
accordance with the principle of fairness, taking into account the specific circumstances.

156. Where a person takes action to avoid danger in an emergency and thereby causes loss to others, if the danger results from natural causes and the action taken by the person is not inappropriate, that person does not bear civil liability. If the injured party makes a demand for compensation, the person who benefitted from the action may be ordered to provide appropriate compensation.

157. Where neither party is at fault with respect to the occurrence of a loss, but one party suffered the loss while engaging in activities for the benefit of the other party or of both parties, the party receiving the benefit may be ordered to provide some monetary compensation.

158. Where, after parents are divorced, a minor child infringes another person's right or interest, the parent who is living with the child must bear civil liability; if it is really difficult for [that] parent to bear the civil liability independently, the parent who is not living with the child may be ordered to bear the civil liability jointly.

159. Where a ward causes damage to another person and the identity of the guardian is clear, the guardian bears civil liability; where it is unclear who the guardian is, the person having the highest priority qualification to serve as guardian bears civil liability.

160. Where an incompetent person who is living and/or studying in kindergarten or school, or a mentally ill person who is receiving treatment in a psychiatric hospital, is injured or causes damage to another person, and the unit is at fault, the unit may be ordered to provide appropriate compensation.

161. Where a tortfeasor had not yet completed his eighteenth year at the time of the tortious act but has completed his eighteenth year at the time of the lawsuit and has financial capacity, he must bear civil liability. Where he lacks financial capacity, the person who had been his guardian must bear civil liability.

Where a person had completed his eighteenth year at the time he committed a tortious act, he must bear civil liability himself. If he lacks financial capacity, the person who supports him must advance the compensation [for him]; where it is difficult to make an advance, the court may order, or mediate an agreement providing for, deferred payment.

162. If in the course of a lawsuit there is a need to stop an infringement, eliminate an obstruction, or remove a danger, the People's Court may issue a decision before the conclusion of the lawsuit based on the application of a party or on its own initiative.

Where in a lawsuit a person has discharged his civil liability by extending an apology, this fact must be clearly stated in the judgment.

163. Where in the course of a lawsuit a related illegal activity is discovered requiring the imposition of sanctions, the court may apply paragraph 3 of article 134 of the General Principles and issue admonitions, 
order repentance, or confiscate property used for illegal activities or things obtained illegally, and/or in accordance with law impose fines and detention.

The imposition of punitive sanctions such as confiscation, fines, and detention must be approved by the President of the People's Court, and should be specified in a separate written order. Where a person who is penalized disagrees with the decision, he may within ten days after receipt of the order apply to the People's Court at the next higher level for review.

164. Fines imposed on citizens under paragraph 3 of article 134 of the General Principles are limited to 500 yuan or less, and detention to fifteen days or less.

Detention imposed as a punitive measure against the legal representative of a legal person should be for fifteen days or less.

The above two paragraphs do not apply where the law provides otherwise.

\section{VI}

\section{Time Limits for Bringing SUIT}

165. Where a person knew or must have known before the General Principles entered into effect that his civil right was infringed, and applied to the People's Court for protection after the General Principles entered into effect, the period of limitation for bringing the lawsuit shall be governed by the provisions of article 135 and article 136 of the General Principles, and must start to run from January 1, 1987.

166. Where at the time the General Principles came into effect, twenty or more years had passed since a person's civil right was infringed, and the person applied to the People's Court for protection after the General Principles came into effect, the period of limitation for bringing the lawsuit should be either two years, as provided in article 135 of the General Principles, or one year, as provided in article 136, starting from January 1, 1987.

167. After the General Principles came into effect, where the two-year period of limitation for a lawsuit provided in article 135 of the General Principles applies, and the person whose right was infringed becomes aware of such fact after eighteen or more years but before twenty years elapse from the time of the injury, or where the one-year limitation period provided in article 136 of the General Principles applies, the person whose right was infringed becomes aware of such fact after nineteen years or more, but before twenty years elapse from the time of the infringement, the right to bring a lawsuit must be exercised within twenty years of the injury, and after twenty years no protection will be provided.

168. The period of limitations for bringing lawsuits involving evident bodily injury starts to run from the date the injury is suffered. If the injury was not immediately discovered at the time it was suffered, and subsequent medical diagnosis proves that the injury was caused by an infringement, the period of limitation starts to run from the date the diagnosis was made. 
169. The "special circumstances" referred to in article 137 of the General Principles include the situation where a person is prevented by objective obstacles from exercising his right to make a claim within the period of limitation provided by law.

170. Claims regarding damage to state property which has not been delegated to citizens or legal persons to operate or manage are not subject to periods of limitation.

171. Where an obligor who performed his obligation after the period of limitation expired seeks to recover his performance on the ground that the period of limitation had expired, his claim is not sustained.

172. Where during the last six months of a period of limitation, a person whose right was infringed is incompetent or has limited competence and does not have a legal representative, or his legal representative has died, has been disqualified, or has become incompetent, that person may be deemed to be unable to exercise his right of claim due to "other obstacles,"'19 in which case suspension of the period of limitation applies.

173. After a period of limitation is cut off because the obligee claims his right or the obligor agrees to perform his obligation, and [then] during the new period of limitation the obligee once more claims his right or the obligor once more agrees to perform his obligations, the period of limitation is deemed cut off once more.

Where an obligee raises a claim against a guarantor of an obligation or against a representative of the debtor or against a person who managed the debtor's property, the period of limitation may be deemed cut off.

174. Where an obligee raises his claim before a People's Mediation Committee or other relevant unit, the period of limitation is cut off at the time such claim is raised. A new period of limitation starts when and if the parties fail to reach agreement through mediation. Where the mediation has resulted in agreement, but the obligor fails to perform his obligations within the period of time provided in the agreement, a new period of limitation must start to run from the time when the period in the agreement expires.

175. The provisions set forth in the General Principles concerning suspension, cutting off, and the extension of periods of limitation may be applied to the periods of limitation provided in article 135 and article 136 of the General Principles.

The provisions on extension, but not those on suspension and cutting off, set forth in the General Principles may be applied to the twenty-year period of limitation provided in article 137 of the General Principles.

176. Where a law or regulation contains special provisions concerning the time period for claims for compensation or objections regarding the quality of goods, such special provisions should govern.

177. Periods of limitation for suits involving inheritance are governed by inheritance law. If, after the inheritance starts, an heir does not express his

19. Under article 139 of the General Principles. 
intention to renounce the inheritance, the inheritance should be deemed accepted; where there is no division of the inherited property, the property is deemed jointly co-owned. The relevant provisions of the General Principles govern the suspension, cutting off, and extension of the periods of limitation.

\section{VII}

\section{Application of Law to Foreign Civil Relationships}

178. Where one or both parties to a civil relationship are foreigners, stateless persons, or foreign legal persons, or the subject matter of the civil relationship is located abroad, or the legal facts that create, change, or destroy a relationship of civil rights or obligations occur abroad, these civil relationships are all foreign civil relationships.

When handling cases involving foreign civil relationships, the People's Court must determine the applicable substantive law in accordance with the provisions of chapter 8 of the General Principles.

179. The competence of a Chinese citizen residing overseas is governed by Chinese law if [he performs] an act within Chinese territory; or if in the country in which he resides, by the law of that country.

180. Where a foreigner conducts civil activities in Chinese territory, if he is incompetent under the law of his home country but is competent under the Chinese law, he must be deemed competent.

181. The competence of a stateless person is ordinarily governed by the law of the country where the person permanently resides; if he does not have a permanent residence, by the law of the country in which he resides.

182. The basic national law for a foreigner with double or multiple nationalities is the law of the country of his domicile or the country with which he has the closest relationship.

183. If a party's domicile is unclear or cannot be determined, the place where he usually resides is his domicile. Where a party has several domiciles, the place that has the closest connection to the civil relationship from which the dispute arose is his domicile.

184. The national law of a foreign legal person is the law of the country where the foreign legal person is registered; the legal person's competence is determined in accordance with its national law.

Civil activities conducted by foreign legal persons within Chinese territory must comply with Chinese law.

185. Where a party has two or more places of business, the place of business that is most closely connected to the civil relationship from which the dispute arose governs. Where the party concerned does not have a place of business, his domicile or his regular place of residence governs.

186. Land, buildings, and other structures that are attached to land and things attached to buildings are real property. Civil relationships such as those involving the title to real property, and [its] sale, lease, pledge, or use are governed by the law where the real property is located. 
187. The law of the place of infringement includes the law of the place where the infringement took place and the law of the place where the consequences of the infringement occurred. If the two laws differ, the People's Court may choose and apply [one].

188. When handling foreign-related divorce cases, the courts of our country apply Chinese law to the divorce and to the property division resulting from the divorce. The validity of the marriage is determined in accordance with the law of the place where the marriage took place.

189. [In the case of] support that parents and children provide each other, or that a husband and wife provide each other, or that other persons having support relationships provide one another, the law of the country to which the person receiving the support is most closely connected must be applied. The nationality or domicile of the person providing support and of the person receiving support and the location of the property which provides the support can all be considered the closest connection of the person receiving support.

190. The establishment, modification, and termination of guardianship is governed by the law of the home country of the ward. Where the ward has his domicile in Chinese territory, Chinese law governs.

191. Where a foreigner dies in Chinese territory, and property he leaves in Chinese territory is neither inherited [by intestate succession] nor bequeathed to any person, the property is disposed of in accordance with Chinese law, unless an international treaty to which China and the home country of the foreigner are parties provides otherwise.

192. Where foreign law must be applied, if different areas in that foreign country have different law, the applicable law must be determined in accordance with the law of that country which governs the conflict of laws within that country. Where the law of such country does not so provide, the law of the region which has the closest connection with the civil relationship is applied directly.

193. Foreign law which must be applied may be proved by evidence provided as follows: (1) by the parties, (2) by the central authority of a country that has entered into a judicial assistance agreement with China, (3) by the Chinese embassy or consulate in the foreign country, (4) by the embassy in China of the foreign country, (5) by domestic or foreign legal experts. If the applicable foreign law cannot be proved using the methods stated above, the law of the People's Republic of China is applied.

194. Acts of parties intended to evade China's mandatory or prohibitive laws do not give rise to the application of foreign law.

195. Limitation periods for foreign civil relationships are determined in accordance with the governing law ascertained under the conflict of law provisions. 


\section{VIII \\ Other Provisions}

196. In cases brought after January 1,1987 , if the civil acts in question occurred before 1987, the law and/or policy in effect at the time when the civil act took place governs. Where the law or policy in effect at that time did not have specific provisions, the cases may be handled with comparative reference to the General Principles.

197. Cases brought up for review or for new trial under the judicial supervision procedure should be handled in accordance with the law or policy in effect at the time of the original trial.

198. Where a time period that parties agree upon does not start from the first day of a month or a year, a month is deemed to consist of thirty days and a year to consist of 365 days.

Where the last day of a time period is a Sunday or other legal holiday or [its designated equivalent] adjusted day, the last day of the time period is the day following the [Sunday or] holiday.

199. Where a time period is calculated on the basis of days, months, or years, if the parties have made an agreement with respect to when the time period starts to run, the agreement governs.

200. Provisions previously promulgated by the Supreme People's Court that are inconsistent with the General Principles and this Opinion are not followed from now on by the People's Courts at various levels when handling civil and economic cases as courts of first instance or as appellate courts. 
